\title{
Transfers, NON-TRADED GOODS, AND UNEMPLOYMENT: AN ANALYSIS OF THE KEYNES - OHLIN DEBATE
}

\author{
STEVEN BRAKMAN \\ CHARLES VAN MARREWIJK
}

CESIFO WORKING PAPER NO. 1588

CATEgORY 7: TRAde POLICY

NOVEMBER 2005

An electronic version of the paper may be downloaded

- from the SSRN website:

www.SSRN.com

- from the CESifo website:

www.CESifo-group.de 


\title{
TRANSFERS, NON-TRADED GOODS, AND UNEMPLOYMENT: AN ANALYSIS OF THE KEYNES - OHLIN DEBATE
}

\begin{abstract}
In the famous debate between Keynes and Ohlin on the transfer problem, the interaction between non-traded goods and unemployment complicates the analysis considerably. We analyze these issues using four different models to conclude that Keynes's concern regarding the large burden imposed on Germany was justified. Simultaneously, we show that Ohlin's presumption that a transfer does not affect the donor's terms-of-trade either favourably or unfavourably was also justified. Moreover, Ohlin was also right in asserting that a transfer tends to lower the price of non-traded goods for the donor and raise them for the recipient.
\end{abstract}

JEL Code: B0, F0, O1.

\author{
Steven Brakman \\ University of Groningen \\ P.O. Box 800 \\ 9700 AV Groningen \\ The Netherlands \\ S.Brakman@eco.rug.nl
}

\author{
Charles van Marrewijk \\ Erasmus University Rotterdam \\ Department of Economics H8-10 \\ P.O. Box 1738 \\ 3000 DR Rotterdam \\ The Netherlands \\ vanmarrewijk@few.eur.nl
}

We would like to thank seminar participants at the University of Groningen, Radboud University Nijmegen, and Erasmus University Rotterdam, two anonymous referees for useful comments and suggestions. Any errors are, of course, our own. 


\section{Introduction}

The economics of international transfers has repeatedly given rise to interesting debates to increase our understanding of the issues involved. The most famous of these was the discussion between John Maynard Keynes and Bertil Ohlin in 1929 regarding Germany's capacity to pay reparations after the First World War and the terms-of-trade effect, see Keynes (1929a-c) and Ohlin (1929a,b). ${ }^{1}$ Ever since he wrote the Economic Consequences of the Peace in 1919, Germany's ability to pay reparations was on Keynes's mind. ${ }^{2}$ The occasion for the famous 1929 debate was a new committee of experts under the American Owen Young. The committee had to reorganize Germany’s reparation payments of the Dawes plan of 1924, scheduling payments of increasing magnitude. In this 1929-debate, Keynes represented a classical, partial equilibrium view and argued that a transfer would cause a terms-oftrade deterioration for the donor. Ohlin, however, pointed at the importance of income effects on demand as a result of the transfer to conclude that there was no presumption for the terms-of-trade to move either in favor of, or against, the donor.

The focus of the literature soon moved to the welfare effects of a transfer. After Leontief (1936) pointed out, by means of an example, the possibility of transfer paradoxes (in which the donor gains and/or the recipient loses from the transfer) the main point of reference has been Samuelson's (1947) assertion that Leontief's example requires instable markets. More specifically, in a perfectly competitive, Walrasian stable, two-country world with two traded goods the donor's welfare falls and the recipient's welfare rises, see also Kemp (1964) and Mundell (1960). We refer to this result (which was hiding in a footnote) as "Samuelson's Theorem." ${ }^{3}$

Samuelson's Theorem does not hold if productive resources are transferred instead of purchasing power, if distortions are present in the system, if aid is tied, or if there are more than two countries. Transfer paradoxes are thus quite possible in more general

\footnotetext{
${ }^{1}$ Two other debates were the bullionist controversy, regarding the convertibility of gold and payments by Great Britain to its allies around 1800, involving e.g. Henry Thornton, David Ricardo and John Wheatley, and the debate in 1980-1983 concerning the importance of third parties, involving e.g. Graciela Chichilnisky, Jagdish Bhagwati and T.N. Srinivasan.

${ }^{2}$ Keynes (1919) calculated that Germany could not possibly pay what the European Allies demanded. He thought that Germany could pay a total of $£ 1500 m$, in thirty annual instalments of £50m. See Skidelsky (1992) for details on the evolution of Keynes's thinking between 1919 and debate of 1929.

${ }^{3}$ See Samuelson (1947, p. 29) and Brakman and Van Marrewijk (1998).
} 
settings, see e.g. Jones (1967, 1985), Ohyama (1974), Gale (1974), Chichilnisky (1980), Bhagwati, Brecher and Hatta (1983), Kemp and Kojima (1985), Schweinberger (1990), Kemp (1995), and Kemp and Shimomura (2003).

In their debate Keynes and Ohlin both acknowledged that non-traded goods exist and that their presence complicates the analysis considerably. Even more so, if unemployment or price rigidities are present. Without either party changing its point of view, Keynes and Ohlin focused on the terms-of-trade effect of a transfer in the presence of non-traded goods, as did the subsequent literature on the transfer problem analyzing non-traded goods, see e.g. McDougall (1965), Samuelson (1971), Chipman (1974), and Jones (1975). Yano and Nugent (1999) analyse the small-country case in which prices of international goods are given. In this case transfer paradoxes can arise if tariffs are introduced as an additional distortion. They show that in practice transfer paradoxes are unlikely in these special cases.

This paper presents and investigates the non-traded goods and unemployment confusion by analyzing international transfers in a simple, but general, two-country dual framework. We focus attention on the welfare effects of a transfer, on the termsof-trade effect, and on the price of traded goods relative to non-traded goods, a point emphasized by Ohlin. Section 2 gives a brief overview of the historical discussion on transfers between Keynes and Ohlin. We summarize their positions at the end of section 2 in four statements. Section 3 briefly provides the analytic framework of four separate models: (i) the standard model, (ii) the non-traded goods model, (iii) the unemployment model, and (iv) the complete model. Section 4 derives and discusses the analytic consequences of a unilateral transfer in these four models in the light of the four assertions made by Keynes and Ohlin identified in section 2. Section 5, finally, summarizes the results and concludes.

\section{Historical overview}

Discussions on transfers often give rise to confusion and misunderstandings. This also holds for the discussion on the effects of transfers in the presence of non-traded goods, particularly in conjunction with unemployment. The first example of this particular confusion is the famous discussion on transfers between Keynes and Ohlin in the Economic Journal in 1929 in which Keynes analyzed the problem of German 
war reparation payments as a classical economist. In essence this means that the current account surplus is the transfer. If this surplus is absent or fails to materialize the terms-of-trade (or the exchange rate) deteriorates. If the price-elasticity of exports is smaller than one, as Keynes believed to be the case for Germany, a paying country is confronted with declining terms-of-trade. If the paying country has to pay reparations over a longer period of time, the terms-of-trade will decline from year to year. It is important to note that not only Keynes and Ohlin discussed these matters in the 1929 volume of the Economic Journal. Most notably Jacques Rueff (1929, p.394) added additional concerns to the debate that prelude the monetary approach to the balance of payments that was developed later. ${ }^{4}$ He argued, contrary to Keynes that: "the commercial balance has shown a tendency to adjust itself to the necessities of the balance of payments, whatever they might be and whatever their origin."

After further discussing the history of France, he concludes (p.395):

"What is remarkable in the case of France after 1870 is that a surplus appeared in the commercial balance at precisely the moment when theory would lead one to expect it. This only constitutes a presumption - but a very strong presumption - in favour of the said theory."

However, according to Keynes this is not the only problem which faced Germany. One of the main problems is that (Keynes, 1929, p. 3):

"...when foreign borrowing (of Germany) comes to an end, it will be a question, not of reducing current consumption in Germany, but of transferring labour from capital works in Germany to the export trades....where the outcome of capital improvements ...is not in exportable form (and much of it will not be in such a form), the diversion of production out of employments into export trades...will have to be on a greater scale then is required by the payment of the Reparations alone...".

Keynes then concludes (p.3) that one of the main problems is not "the release to foreign consumers of goods now consumed by Germans, but the diversion of German factors of production from other employments into the export industries."

The increase of exports is crucial in Keynes's thinking. He considered this as "a formidable task" and even if efficiency wages are reduced this may not help to increase Germany's exports, or might even make her worse off, in the case (p.5):

"where the output, e.g. personel services or buildings, cannot be exported anyhow."

\footnotetext{
${ }^{4}$ The introduction of money requires that time is introduced explicitly - money is only held if it can be used to buy commodities tomorrow - this however, does not affect the general conclusions of the models described in the next section (see Brakman and Van Marrewijk, 1998, section 10.3).
} 
So, in the eyes of Keynes the existence of non-traded goods very much reduced Germany's capacity to pay. In Keynes's analysis this is a major concern, because (relative) prices in the traded goods sector must decrease in order to make the transfer possible, making such a diversion of German factors of production into the traded goods sector unlikely. Ohlin (1929, p.175), in his comment to Keynes, points out that the existence of a non-tradable sector does not alter his main point, namely that income effects can make terms-of-trade adjustments redundant in principle.

The presence of non-traded goods complicates the analysis considerably, and certainly has not made the discussion between Keynes and Ohlin more transparent. Keynes thought that their presence strengthened his case. The consequences of non-traded goods for the transfer problem are still problematic, as the latest edition of the bestselling textbook of Krugman and Obstfeld (2006) shows. They point out that the United States spend only a fraction of income on foreign goods, just like Keynes pointed this out for Germany in 1929. Obviously, this gives us no information at all on the marginal propensities to consume a particular good for Germany or the United States. ${ }^{5}$ Moreover, Krugman and Obstfeld (2006, p. 98) argue:

"Here the crucial point is that a country's non-traded goods compete with exports for resources. A transfer of income from the United States to the rest of the world lowers the demand for non-traded goods in the United States, releasing resources that can be used to produce U.S. exports. As a result, the supply of U.S. exports rises. .. The result is that a transfer by the United States to other countries may lower the price of U.S. exports relative to foreign, worsening U.S. terms-of-trade."

They then conclude on the basis of this reasoning that "Keynes was right in practice." However, the above quote suffers from two omissions. First, resources released from the production of non-traded goods in the U.S. could also be used for the production of goods otherwise imported. Second, and more importantly, the transfer to the rest of the world has increased the demand for U.S. exports, as stressed time and again by Ohlin. Indeed, Ohlin argues that (1929a, p. 174):

\footnotetext{
${ }^{5}$ Suppose, for example, that there are two countries with an income level of 100, each spending 50 on traded good $x$ and 50 on traded good $y$, while one country produces (in value terms) 60 of $x$ and 40 of $y$ and the other 40 of $x$ and 60 of $y$. Then the observation that both countries only spend 10 percent on foreign goods says nothing about the average propensities to consume, let alone the marginal propensities to consume.
} 
"Home market prices tend to rise in $A$ [that is: the recipient] and fall in $B$ [that is: the donor], relative to prices of export and import goods and prices of the goods which compete with import goods. .. It is not necessary that A's export prices should rise and B's fall. Thus, B need not offer its goods on cheaper terms-of-trade to induce A to take a greater quantity of them. Indirectly, however, it is probable that a certain shift of the terms of exchange will take place."

So, he notes that in the presence of non-traded goods price changes might happen but that these are not necessary, as Keynes believed. Ohlin (1929, p.175) concludes :

"This erroneous conclusion is reached because of the fact that the shift in buying power is ignored, except in so far as it directly affects demand for international goods."

To be fair to Keynes we also deal with the possibility of unemployment and rigidity. ${ }^{6}$ As Keynes (1929a, p. 6) stresses, and what is also forcefully put forward by Rueff who cites Keynes (1929, p. 390):

"In the case of German reparations, we are trying to fix the volume of foreign remittances and compel the balance of trade to adjust itself thereto. Those who see no difficulty in this... are applying the theory of liquids to what is, if not a solid, at least a sticky mass with strong internal resistances."

To settle the issue of the terms-of-trade effect of an international transfer and its relation to non-traded goods we first need to extend Samuelson's result on the welfare effects of a transfer to non-traded goods. Furthermore, we allow for the possibility of unemployment and rigidity. At this point it is fair to point out that Keynes was not the ignoramus as he is sometimes portrayed to be in this debate (Keynes, 1929a, p.2):

"If 1 pound is taken from you and given to me and I choose to increase my consumption of precisely the same goods as those of which you are compelled to diminish yours, there is no Transfer problem."

However, he thought that this was only a special case. Keynes was very much a practical man in this discussion and he was convinced that Germany could never pay the total of war reparations.

For Keynes this was not the first time he was worried about the possibilities of Germany to pay war reparations, as is illustrated in his The Economic Consequences of the Peace (1919). In the transfer debate of 1929 he was uneasy that the debate became more and more theoretical instead of practical (Keynes, 1929c, p. 404): "the

\footnotetext{
${ }^{6}$ We are grateful to one of the anonymous referees for drawing our attention to Rueff (1929).
} 
controversy...moves quite inevitably, from the particular (that is, Germany) to the general." From a practical point view he turned out to be right; Germany could never pay the huge amount it should pay and the fact that it was forced to do so helped to pave the way for Hitler. As Kershaw (1999, p. 355) notes:

"With the Brüning government under siege, ruling by emergency decree, its policies - calculated to demonstrate Germany's inability to pay reparations - sending the economy plummeting to disaster in a catastrophic downward spiral of cascading production levels and soaring levels of unemployment and social mysery, more and more voters were cursing the wretched Republic [the Weimar republic]."

Our analysis below is general. The analysis simplifies, however, if we make the standard assumption in international economics of an identical demand structure. ${ }^{7}$ For ease of reference, we label this assumption 1.

- Assumption 1. Donor and recipient have an identical demand structure: $\bar{m}_{u}^{A}=\bar{m}_{u}^{B}$

Moreover, we summarize the assertions made by Keynes and Ohlin as discussed above in four statements:

- Keynes's concern: transfers impose a (large) burden on the donor; this holds particularly for Germany in the presence of non-traded goods and price rigidities.

- Keynes's presumption: a transfer deteriorates the donor's terms-of-trade, specifically in the presence of non-traded goods.

- Ohlin's presumption I: there is no reason for a transfer to affect the donor's termsof-trade either favourably or unfavourably.

- Ohlin's presumption II: the price of non-traded relative to traded goods will rise for the recipient and fall for the donor. ${ }^{8}$

\footnotetext{
${ }^{7}$ See, for example, p.6 in Bowen, et al. (1998).

${ }^{8}$ It is interesting to note that Harry Johnson concurred with this presumption. In the final section of Johnson (1976) he notes that additional income for the recipient increases the demand for non-traded goods, which (initially) leads to price increases of non-tradables. He argues that the subsequent substitution process can be in the direction of importables or exportables, but "since there is no reason to assume that the effect is biased one way or the other, p.219" the introduction of non-tradables has no bearing on the discussion. In the sections below we show the importance of Ohlin's second presumption in the debate.
} 


\section{The models ${ }^{9}$}

We analyze international transfers under four different settings of perfect competition if there are two countries (donor $A$ and recipient $B$ ) and two traded goods (numéraire good $x$ and good $y$ with price $p$ ). The settings are referred to as (i) the standard model (no unemployment or non-traded goods), (ii) the non-traded goods model (with a nontraded good for both donor and recipient), (iii) the unemployment model (with unemployment in the donor country), and the complete model (with both non-traded goods and donor unemployment). We let $J=A, B$ be the country index, $q^{J}$ is the price of the locally provided non-traded good, $E^{J}$ is the expenditure function, $R^{J}$ is the revenue function, $T$ is the transfer from country $A$ to country $B, u^{J}$ is the welfare level, $v^{A}$ is employment in country $A, w^{A}$ is the real wage in country $A$, and $m^{J}$ is the net demand for good $y$, i.e. $m^{J}=E_{p}^{J}-R_{p}^{J}$, where subscripts refer to derivatives. ${ }^{10}$ The equations below are used to construct the various models mentioned above.

$$
\begin{aligned}
& E^{A}\left(p, q^{A}, u^{A}\right)=R^{A}\left(p, q^{A}, v^{A}\right)-T \\
& E_{q}^{A}\left(p, q^{A}, u^{A}\right)=R_{q}^{A}\left(p, q^{A}, v^{A}\right) \\
& R_{v}^{A}\left(p, q^{A}, v^{A}\right)=w^{A} \\
& E^{B}\left(p, q^{B}, u^{B}\right)=R^{B}\left(p, q^{B}\right)+T \\
& E_{q}^{B}\left(p, q^{B}, u^{B}\right)=R_{q}^{B}\left(p, q^{B}\right) \\
& m^{A}\left(p, q^{A}, u^{A}, v^{A}\right)+m^{B}\left(p, q^{B}, u^{B}\right)=0
\end{aligned}
$$

Equation (1) is the donor's budget constraint. It indicates that total expenditure $E^{A}$, which is a function of the prices $p$ and $q^{A}$ and the attained welfare level $u^{A}$, is equal to total revenue $R^{A}$, which is a function of the prices $p$ and $q^{A}$ and the employment level $v^{A}$, after subtracting the transfer to country $B$ (measured in terms of good $x$ ). Similarly, equation (4) is the recipient's budget constraint. As we do not analyze unemployment for the recipient, the argument $v^{B}$ is suppressed. Equation (2) is the donor's market clearing condition for non-traded goods. Making use of the derivative properties of expenditure and revenue functions, domestic demand $E_{q}^{A}$ must be equal

\footnotetext{
${ }^{9}$ Detailed derivations can be found in the appendix.

${ }^{10}$ Note, that the model assumes non-satiable wants. The case of satiable wants in the context of transfers was analyzed by Johnson (1976).
} 
to domestic supply $R_{q}^{A}$. Similarly, equation (5) is the recipient's market clearing condition for non-traded goods, where the argument $v^{B}$ is again suppressed. If we analyze unemployment in the donor country, we will always assume that the sticky real wage rate $w^{A}$ is a binding restriction, such that actual employment $v^{A}$ is endogenously (demand) determined, see equation (3). Finally, using again the derivative properties, equation (5) is the market clearing condition for traded good $y$. The four models mentioned above can now be summarized as follows.

- The standard model ignores non-traded goods and unemployment; it consists of equations (1), (4), and (6), with the endogenous variables $p, u^{A}$, and $u^{B}$.

- The non-traded goods model ignores unemployment; it consists of equations (1), (2), (4), (5), and (6), with the endogenous variables $p, q^{A}, q^{B}, u^{A}$, and $u^{B}$.

- The unemployment model ignores non-traded goods; it consists of equations (1), (3), (4), and (6), with the endogenous variables $p, v^{A}, u^{A}$, and $u^{B}$.

- The complete model incorporates non-traded goods and unemployment; it consists of equations (1)-(6), with the endogenous variables $p, q^{A}, q^{B}, v^{A}, u^{A}$, and $u^{B}$.

For the models incorporating non-traded goods, we will simplify the analysis by eliminating equations (2) and (5), which can be solved for the price of non-traded goods $q^{J}$ for donor and recipient as a function of the price $p$ of good $y$, employment $v^{A}$, and domestic welfare $u^{J}$ :

$$
\begin{aligned}
& q^{A}=q^{A}\left(p, u^{A}, v^{A}\right) ; \quad q^{B}=q^{B}\left(p, u^{B}\right), \quad \text { with } \\
& q_{v}^{A}=\frac{R_{q v}^{A}}{\left(E_{q q}^{A}-R_{q q}^{A}\right)} ; \quad q_{p}^{J}=-\frac{\left(E_{q p}^{J}-R_{q p}^{J}\right)}{\left(E_{q q}^{J}-R_{q q}^{J}\right)}, \quad q_{u}^{J}=-\frac{E_{q u}^{J}}{\left(E_{q q}^{J}-R_{q q}^{J}\right)}, J=A, B
\end{aligned}
$$

Note that if there is any substitution at all in either production or consumption of the non-traded good in country $J$, then equation (7) is well defined for that country (that is $E_{q q}^{J}-R_{q q}^{J}<0$ ), as we henceforth assume. Also note that if the traded good $y$ and the non-traded good are net substitutes (that is $E_{q p}^{J}-R_{q p}^{J}>0$ ), then $q_{p}^{J}$ is positive, while if the non-traded good is a normal good (that is $E_{q u}^{J}>0$ ), then $q_{u}^{J}$ is also positive. 


\section{The results}

For each of the models introduced in section 3 we now briefly provide and discuss the main analytic results, identified by sub-indices st, $n t$, un, and co for the standard, nontraded goods, unemployment, and complete model, respectively.

\subsection{The standard model}

The basic economic implications of international transfers are most easily understood by restricting attention to the standard model, that is by allowing for two traded goods, two countries, perfect competition, and no imperfections. We normalize such that $E_{u}^{J}=1$ and define $\Omega$ and $\Delta$ for notational convenience as follows:

$$
\Omega \equiv \sum_{J} m_{p}^{J}<0 ; \quad-1 / \Delta \equiv \sum_{J}\left(m_{p}^{J}-m^{J} m_{u}^{J}\right)<0
$$

The term $\Omega$ is always non-positive as it is the derivative of the compensated net demand for good $y$ with respect to its own price $p$. If there is some substitutability in either demand or supply (or both) between good $y$ and good $x$, the term will be strictly negative, as we henceforth assume. The positively defined term $\Delta$ is associated with Walrasian stability, based on a dynamic adjustment process where the price falls (rises) if it is higher (lower) than the equilibrium price, see Brakman and van Marrewijk (1998, pp. 39 - 41) for details. Differentiating equations (1), (4), and (6) with respect to $p, u^{A}, u^{B}$ and $T$, solving these equations, and imposing Walrasian stability gives the following the terms-of-trade and welfare effects:

$$
\begin{aligned}
& \left.\frac{d p}{d T}\right|_{s t}=\left(m_{u}^{B}-m_{u}^{A}\right) \Delta>0 \Leftrightarrow m_{u}^{B}>m_{u}^{A} \\
& \left.\frac{d u^{A}}{d T}\right|_{s t}=\Omega \Delta<0 ;\left.\quad \frac{d u^{B}}{d T}\right|_{s t}=-\Omega \Delta>0 ;\left.\quad \frac{d u^{A}}{d T}\right|_{s t}+\left.\frac{d u^{B}}{d T}\right|_{s t}=0
\end{aligned}
$$

Equation (9) indicates that the price of good $y$ will rise, if and only if $m_{u}^{B}>m_{u}^{A}$, that is if the recipient's marginal propensity to consume good $y$ is higher than the donor's propensity to consume this good. Obviously, there is no terms-of-trade effect if the demand structure is identical (Assumption 1). Even if there are demand differences, however, the donor may either export or import good $y$, so there is no presumption that the terms-of-trade will move against the donor. Equation (10) indicates that the transfer indeed imposes a burden on the donor as its welfare decreases. Similarly, the 
transfer is welcomed by the recipient, whose welfare increases. Finally, as there are no imperfections in the standard model, there is no room for Pareto improvements.

Result 1. In the standard model: Keynes's concern is valid (donor burden), as is Ohlin's presumption I (neutral terms-of-trade effect)

\subsection{The non-traded goods model}

One of the central points in section 2 is that the discussion between Keynes and Ohlin was complicated by the presence of non-traded goods. The non-traded goods model provided in section 3 is used to analyze these issues. It is convenient to define analogous terms as in the standard model:

$$
\begin{aligned}
& \bar{m}_{r}^{J} \equiv m_{r}^{J}+m_{q}^{J} q_{r}^{J}, \quad r=u, p ; \quad \Omega \equiv \sum_{J} m_{p}^{J} ; \\
& -1 / \bar{\Delta} \equiv \sum_{J}\left(\bar{m}_{p}^{J}-m^{J} \bar{m}_{u}^{J}\right)<0
\end{aligned}
$$

The inequality in the last term of equation (8') is again based on Walrasian stability. All the definitions take the non-traded goods effects into consideration. Take, for example, the term $m_{u}^{A}=m_{u}^{A}+m_{q}^{A} q_{u}^{A}$. It consists of the sum of $m_{u}^{A}$ and $m_{q}^{A} q_{u}^{A}$. The former is the regular marginal propensity to consume good $y$, while the latter is the indirect effect on this marginal propensity through the non-traded goods sector. If good $y$ and the non-traded good are substitutes, the term $m_{q}^{A}$ is positive. If the nontraded good is a normal good, the term $q_{u}^{A}$ is positive, see section 3. Under those circumstances, then, the total marginal propensity to consume good $y$ is positive if the direct effect dominates the indirect effect, see also below.

For analytic purposes, it is important to sign the term $\Omega$. From the definition of $\Omega$ and equation (7) it follows that

$$
\bar{\Omega}=\sum_{J}\left(m_{p}^{J}-\frac{\left(m_{q}^{J}\right)^{2}}{\left(E_{q q}^{J}-R_{q q}^{J}\right)}\right)
$$

Thus, using the definition of $m^{J}$ in (11), a sufficient condition for $\bar{\Omega}$ to be negative is for each term in the summation in (11) to be negative, that is

$$
E_{p p}^{J}-R_{p p}^{J}-\frac{\left(E_{p q}^{J}-R_{p q}^{J}\right)^{2}}{\left(E_{q q}^{J}-R_{q q}^{J}\right)}<0 \quad \text { for } J=A, B
$$


Since the net expenditure function $E^{J}-R^{J}$ is concave in prices both conditions in (12) are satisfied. ${ }^{11}$ The term $\Omega$ is therefore unambiguously negative. Differentiating equations (1), (2), (4), (5), and (6), with respect to $p, q^{A}, q^{B}, u^{A}, u^{B}$, and $T$, solving the equations, and imposing Walrasian stability gives:

$$
\begin{aligned}
& \left.\frac{d p}{d T}\right|_{n t}=\left(\bar{m}_{u}^{B}-\bar{m}_{u}^{A}\right) \bar{\Delta}>0 \Leftrightarrow \bar{m}_{u}^{B}>\bar{m}_{u}^{A} \\
& \left.\frac{d u^{A}}{d T}\right|_{n t}=\bar{\Omega} \bar{\Delta}<0 ;\left.\quad \frac{d u^{B}}{d T}\right|_{n t}=-\bar{\Omega} \bar{\Delta}>0 ;\left.\quad \frac{d u^{A}}{d T}\right|_{n t}+\left.\frac{d u^{B}}{d T}\right|_{n t}=0
\end{aligned}
$$

Equation (9') indicates that the price of good $y$ will rise, if and only if $m_{u}^{B}>m_{u}^{A}$, that is if the recipient's direct plus indirect marginal propensity to consume good $y$ is higher than the donor's direct plus indirect propensity to consume this good. Again, there is no terms-of-trade effect if the demand structure is identical (Assumption 1) and even if there are demand differences, the donor may either export or import good $y$, so there is no presumption that the terms-of-trade will move against the donor. Equation (10') indicates that the transfer also imposes a burden on the donor in a nontraded goods setting (as its welfare decreases) and is welcomed by the recipient (as its welfare increases). Since the marginal rate of substitution is equal to the marginal rate of transformation both internationally (between traded goods) and domestically (between traded and non-traded goods), Pareto improvements are again not possible.

What about relative prices? Keynes was convinced that a major aspect of the transfer problem was to divert factors of production from the non-traded to the traded goods sector. This problem becomes more important if relative prices of traded versus nontraded goods decline. Suppose, then, that there is no terms-of-trade effect as a result of the transfer. How about the price of non-traded goods? From (7) it follows that

$$
\left.\frac{q^{J}}{d T}\right|_{n t}=\left.q_{u}^{J} \frac{d u^{J}}{d T}\right|_{n t}+\left.q_{p}^{J} \frac{d p}{d T}\right|_{n t}
$$

\footnotetext{
11 The matrix of second-order price derivatives is negative semi-definite, such that $\left(E_{p p}^{J}-R_{p p}^{J}\right)\left(E_{q q}^{J}-R_{q q}^{J}\right)-\left(E_{p q}^{J}-R_{p q}^{J}\right)^{2}>0$. This, in conjunction with $\left(E_{q q}^{J}-R_{q q}^{J}\right)<0$, gives (12).
} 
Thus, if $d p /\left.d T\right|_{n t}=0$ we can conclude for the recipient that the sign of $d q^{B} /\left.d T\right|_{n t}$ is the same as the sign of $q_{u}^{B}$ (since $d u^{B} /\left.d T\right|_{n t}$ is positive, see equation (10')), which in turn is the same as the sign of $E_{q u}^{B}$, see (7). Therefore, the recipient's price of nontraded goods rises if, and only if, the marginal propensity to consume non-traded goods is positive. Similar reasoning with a reverse effect holds for the donor of the transfer, which therefore experiences a fall in the price of non-traded goods. Even if the price $p$ of traded good $y$ changes, it is obvious from equation (13) that the above conclusions on the changes in the price of non-traded relative to traded goods for donor and recipient still holds if we construct a price index of traded goods in which the weight given to good $y$ equals $q_{p}^{J}$ (this weight is positive if non-traded goods and good $y$ are net substitutes). ${ }^{12}$ To summarize the above discussion:

Result 2. In the non-traded goods model: Keynes's concern is valid (donor burden), as is Ohlin's presumption I (neutral terms-of-trade effect) and Ohlin's presumption II (the price of non-traded goods rises for the recipient and falls for the donor)

\subsection{The unemployment model}

As discussed in section 2, Keynes's concern regarding Germany's ability to pay for the imposed international transfers was partially based on a potential exacerbation of Germany's high unemployment rate at the time of the debate. In effect, the transfer may shift resources into or out of the unproductive 'unemployment' sector, see Bhaduri and Skarstein (1996). Before turning to the interaction between non-traded goods and unemployment, we first analyze the model of sticky-wage unemployment outlined in section 3 in the absence of non-traded goods, see also Berthélemy (1988) and Beladi (1990). It is convenient to define:

$$
\begin{aligned}
& \varepsilon^{A} \equiv\left(\partial w^{A} / \partial p\right)\left(p / w^{A}\right)=R_{p v}^{A}\left(p / R_{v}^{A}\right) ; \\
& \eta^{A} \equiv-\left(\partial w^{A} / \partial v\right)\left(v / w^{A}\right)=-R_{v v}^{A}\left(v / R_{v}^{A}\right)>0 ; \\
& -1 / \tilde{\Delta} \equiv-1 / \Delta+\left(\varepsilon^{A} w^{A} v / \eta^{A} p^{2}\right)\left(p m_{u}^{A}-\varepsilon^{A}\right)<0
\end{aligned}
$$

\footnotetext{
12 See also McDougall (1965), who uses a Divisia price index for traded goods.
} 
The terms $\varepsilon^{A}$ and $\eta^{A}$ are two elasticities, where $\varepsilon^{A}$ is the donor's Stolper-Samuelson factor price elasticity for good $y$. In a standard Heckscher-Ohlin model, $\varepsilon^{A}$ will be larger than 1 if good $y$ uses factor $v$ (labor in this case) intensively and negative if good $x$ uses factor $v$ intensively. Alternatively, $\varepsilon^{A}$ will be positive but smaller than 1 in a Ricardo-Viner model, see Dixit and Norman (1980). The positively defined elasticity $\eta^{A}$ indicates how quickly the real wage rate falls if employment rises. The last inequality is again based on Walrasian stability. Differentiating equations (1), (3), (4), and (6), with respect to $p, v^{A}, u^{A}, u^{B}$, and $T$, solving the equations, and imposing Walrasian stability gives:

$$
\begin{aligned}
\text { (9”) }\left.\frac{d p}{d T}\right|_{u n}=\left(m_{u}^{B}-m_{u}^{A}\right) \widetilde{\Delta}>0 \Leftrightarrow m_{u}^{B}>m_{u}^{A} \\
\text { (10”) }\left.\frac{d u^{A}}{d T}\right|_{u n}=-1-\left.m^{A} \frac{d p}{d T}\right|_{u n}+\left.w^{A} \frac{d v^{A}}{d T}\right|_{u n} ;\left.\frac{d u^{B}}{d T}\right|_{u n}=1-\left.m^{B} \frac{d p}{d T}\right|_{u n} \\
\left.\frac{d u^{A}}{d T}\right|_{u n}+\left.\frac{d u^{B}}{d T}\right|_{u n}=\left.w^{A} \frac{d v^{A}}{d T}\right|_{u n}=\left.w^{A}\left(\frac{\varepsilon^{A} v^{A}}{\eta^{A} p}\right) \frac{d p}{d T}\right|_{u n}
\end{aligned}
$$

The first thing to note from equation (9”) is that the price of good $y$ rises, if and only if $m_{u}^{B}>m_{u}^{A}$, that is if the recipient's marginal propensity to consume good $y$ is higher than the donor's propensity to consume this good, just like in the standard model. Our conclusions regarding the terms-of-trade effect are therefore not affected by incorporating unemployment in the model. The welfare effects, however, are less clear cut. Since unemployment represents a distortion in the model, neither the donor's nor the recipient's welfare effect can be signed in general. For that reason, equation (10") is written to identify the main welfare effects. The recipient is confronted with a positive direct welfare effect from receipt of the transfer (the term 1 in equation (10”)) and a terms-of-trade effect (the term $-m^{B}\left(d p /\left.d T\right|_{u n}\right)$ in equation (10”)), which is positive if the price of the recipient's export good rises. The donor is confronted with a similar terms-of-trade effect and a negative direct transfer effect. In addition, the donor faces an employment effect (the term $w^{A}\left(d v^{A} /\left.d T\right|_{u n}\right)$ in equation (10")), which is positive if total employment rises. If the latter is the case, the transfer causes a positive total welfare effect. In theory, this employment effect can be so large 
that a Pareto improvement is possible (welfare increase for both donor and recipient). The employment effect, however, may also work in the opposite direction, by reducing total welfare and making the donor even worse off, which was one of Keynes's concerns (in which case there could be a welfare decrease for both donor and recipient). Note, however, that under identical demand conditions (assumption 1) none of this is relevant. In that case, both the terms-of-trade effect and the employment effect are zero. This leads to:

Result 3. In the unemployment model: Keynes's concern is valid (donor burden), as is Ohlin's presumption I (neutral terms-of-trade effect).

\subsection{The complete model}

The effect of international transfers in the presence of non-traded goods and unemployment can be analyzed in the complete model. The analysis in the preceding sections is useful for understanding the main effects of the complete model, particularly under assumption 1 . As we did when moving from the standard to the non-traded goods model (from section 4.1 to section 4.2), we define analogous terms incorporating the direct and indirect (non-traded goods) effects when moving from the unemployment model to the complete model (from section 4.3 to this section), see equation $\left(8^{\#}\right)$. In this case, however, there is an additional complication, arising from the interaction between non-traded goods and unemployment. This can be most easily understood by looking at equation (3): $R_{v}^{A}\left(p, q^{A}, v^{A}\right)=w^{A}$.

- In the absence of non-traded goods, this reduces to $R_{v}^{A}\left(p, v^{A}\right)=w^{A}$, implying that any changes in employment are caused exclusively by changes in the terms-oftrade. Under assumption 1, there are no changes in the terms-of-trade, and hence no employment effects (see section 4.3).

- If there are non-traded goods, however, changes in employment can be caused either by changes in the terms-of-trade $p$ or by changes in the price of non-traded goods $q$. Now recall from the non-traded goods section 4.2 that even if there is no change in the terms-of-trade (assumption 1), there still is a change in the price of 
non-traded goods. In the complete model, then, this change in the price of nontraded goods will affect employment, and hence indirectly the terms-of-trade. ${ }^{13}$

$$
\begin{aligned}
& \bar{m}_{v}^{A}=\left(m_{v}^{A}+m_{q}^{A} q_{v}^{A}\right) ; \quad \bar{R}_{v r}^{A} \equiv\left(R_{v r}^{A}+R_{v q}^{A} q_{r}^{A}\right), r=p, u, v \\
& -1 / \hat{\Delta} \equiv\left(1+w^{A} \bar{R}_{v u}^{A} / \bar{R}_{v v}^{A}\right)(-1 / \bar{\Delta})+\left(m^{A} \bar{R}_{v u}^{A}-\bar{R}_{v p}^{A}\right)\left(w^{A} \bar{m}_{u}^{A}+\bar{m}_{v}^{A}\right) / \bar{R}_{v v}^{A}<0
\end{aligned}
$$

The inequality denotes Walrasian stability. ${ }^{14}$ Differentiating equations (1)-(7) with respect to $p, q^{A}, q^{B}, v^{A}, u^{A}, u^{B}$, and $T$, and solving the equations gives:

$$
\begin{aligned}
\left.\left(9^{\#}\right) \quad \frac{d p}{d T}\right|_{c o} & =\left[\left(m_{u}^{B}-m_{u}^{A}\right)+\left(\bar{R}_{v u}^{A} / \bar{R}_{v v}^{A}\right)\left(w^{A} m_{u}^{A}+m_{v}^{A}\right)\right] \hat{\Delta} \\
\left.\left(10^{\#}\right) \frac{d u^{A}}{d T}\right|_{c o} & =-1-\left.m^{A} \frac{d p}{d T}\right|_{c o}+\left.w^{A} \frac{d v^{A}}{d T}\right|_{c o} ;\left.\frac{d u^{B}}{d T}\right|_{c o}=1-\left.m^{B} \frac{d p}{d T}\right|_{c o} \\
\left.\frac{d u^{A}}{d T}\right|_{c o} & +\left.\frac{d u^{B}}{d T}\right|_{c o}=\left.w^{A} \frac{d v^{A}}{d T}\right|_{c o}=w^{A}\left[\left(m_{u}^{B}-m_{u}^{A}\right)-\left(\bar{R}_{v u}^{A} / \bar{\Delta}\right)\right]\left(\hat{\Delta} / \bar{R}_{v v}^{A}\right)
\end{aligned}
$$

It is evident from equation $\left(9^{\#}\right)$ that even with an identical demand structure (assumption 1) there will be a change in the terms-of-trade caused by the indirect effect of the change in the price of non-traded goods, as outlined above. In general, as in the case of the unemployment model, no definite conclusions regarding the welfare effects can be drawn. As a result of the interaction between non-traded goods and unemployment, this even holds under an identical demand structure. ${ }^{15}$ We can, however, draw conclusions on the employment effects under assumption 1, and hence on the total welfare effect. From the last equation in $\left(10^{\#}\right)$ it is clear that the employment effect depends crucially on the sign of $\bar{R}_{v u}^{A} / \bar{R}_{v v}^{A}$ since $\bar{\Delta}$ and $\hat{\Delta}$ are positive. Assuming that the direct effect dominates the indirect effect, we know that $\bar{R}_{v v}^{A}<0$. From the definition, it follows that $\bar{R}_{v u}^{A} \equiv\left(R_{v u}^{A}+R_{v q}^{A} q_{u}^{A}\right)=R_{v q}^{A} q_{u}^{A}$. If non-traded goods are normal goods $q_{u}^{A}>0$. Finally, we know that depending on the labour

\footnotetext{
${ }^{13}$ This result is exactly what Ohlin (1929a, p. 174) had in mind “...It is not necessary that A's export prices should rise and B's fall. Thus, B need not offer its goods on cheaper terms-of-trade to induce A to take a greater quantity of them. Indirectly, however, it is probable that a certain shift of the terms of exchange will take place."

${ }^{14}$ Note that we could define elasticities analogous to those of section 4.3 on the basis of $\bar{R}_{v r}^{A}$.

${ }^{15}$ We do not think it is very likely that the indirect effect is large enough to cause a welfare paradox (donor enrichment or recipient impoverishment), but we are unable to rule this out analytically.
} 
intensity of non-traded goods $R_{v q}^{A}$ can be positive or negative (see the discussion with respect to equation 8”). In a Ricardo-Viner model, which reflects Keynes’s world of

rigidities better than the neo-classical world, $R_{v q}^{A}>0$, and hence $\bar{R}_{v u}^{A}>0$. Under assumption 1, therefore, the employment effect is positive. The transfer tends to alleviate the distortion imposed on the donor economy, and thereby mitigates the negative welfare effect imposed on the donor, weakening Keynes’s concern.

Result 4. In the complete model: Keynes's concern is weakened (donor burden) and Ohlin's presumption I (neutral terms-of-trade effect) is valid.

\section{Summary and conclusions}

Keynes's concern regarding the economic burden imposed on Germany after World War I with respect to the reparations payments can be based on four effects:

A. The direct burden of the transfer, indicating that Germany had to give up real resources that could have been used for its own consumption and reconstruction.

B. The indirect burden of a transfer through a deteriorating terms-of-trade.

C. The indirect burden of a transfer through rising unemployment.

D. The indirect burden of a transfer through a change in the price of non-traded goods, which may exacerbate the unemployment problem.

We analyze these concerns using four different settings incorporating non-traded goods and unemployment, as summarized in Table 1. On the basis of assumption 1, we now briefly relate these results to the Keynes - Ohlin debate (as reviewed in section 2). See the main text, however, for details of the analysis. From a practical point of view, Keynes's concern regarding the burden imposed on Germany certainly seems to be valid. The donor is worse off and the recipient is better off in the standard model, the non-traded goods model, and the unemployment model. Since the interaction between non-traded goods and unemployment in the complete model in general leads to a reduction of unemployment, thus mitigating this distortion, Keynes's concern is weakened in the complete model. 
Table 1 Summary of results for the four models

1.a Summary of effects under assumption 1

\begin{tabular}{l|cccc} 
& \multicolumn{4}{|c}{ type of model } \\
& standard & non-traded & unemployment & complete \\
\hline donor terms-of-trade & 0 & 0 & 0 & $?$ \\
donor welfare & - & - & - & $?$ \\
recipient welfare & + & + & + & $?$ \\
donor price non-traded goods & n.a. & $-^{*}$ & n.a. & $?$ \\
recipient price non-traded goods & n.a. & $+^{*}$ & n.a. & $?$ \\
donor employment & n.a. & n.a. & 0 & $+^{* *}$ \\
\hline \hline
\end{tabular}

1.b Summary of results under regular supply and demand conditions

Keynes's concern

Keynes's presumption

Ohlin's presumption I

Ohlin’s presumption II

\begin{tabular}{|cccc} 
valid & valid & valid & weakened \\
not valid & not valid & not valid & not valid \\
valid & valid & valid & valid \\
n.a. & valid & n.a. & unclear
\end{tabular}

n.a. = not applicable;

${ }^{*}$ if non-traded goods are normal $\left(q_{u}^{J}>0\right)$; ${ }^{* *}$ if non-traded goods are normal and $\bar{R}_{v q}^{A}>0$

In the presence of non-traded goods, Ohlin's presumption II, that the price of nontraded relative to traded goods will rise for the recipient and fall for the donor, is also valid. It is readily understood from the fact that, other things equal, the transfer increases demand for non-traded goods for the recipient and reduces demand for the donor. Although this force is also operative in the complete model, no clear conclusions can be drawn in this setting because both the terms-of-trade and the employment level will change, and both these changes will also affect the price of non-traded goods relative to traded goods.

Ohlin's presumption I, that there is no reason for a transfer to affect the donor's terms-of-trade either favourably or unfavourably is valid under all circumstances. This implies, simultaneously, that Keynes's presumption that a transfer worsens the donor's terms-of-trade is not valid. In most cases, a terms-of-trade change is not necessary at all in response to an international transfer because the recipient's increase 
in demand is offset by the donor's decrease in demand. Only in the complete model is a change in the terms-of-trade necessary; this follows from the fact that, in the absence of any other changes, the reduction in the donor's demand for non-traded goods causes a price change for non-traded goods, starting off a series of indirect price effects through the production and demand structure.

Finally, it is clear from the top part of Table 1 that the most important economic effects of an international transfer cannot be unambiguously signed in the complete model, incorporating both non-traded goods and unemployment. This makes the largely unresolved Keynes - Ohlin discussion understandable. Our analysis discusses not only the most important economic consequences in a framework of non-traded goods and a framework of unemployment, but also how the interaction between these two phenomena complicate the analysis in the complete model. In short, it shows the value of analytic model building in guiding the discussion and our understanding.

\section{References}

Beladi, H. (1990), “Unemployment and immiserizing transfer,” Journal of Economics 52: 253-265.

Berthélemy, J.-C. (1988), "The transfer paradox in a non-Walrasian context," Weltwirtschaftliches Archiv 124: 420-434.

Bhaduri, A., and R. Skarstein (1996), "Short-period macroeconomic aspects of foreign aid,” Cambridge Journal of Economics 20: 195-206.

Bhagwati, J.N., R.A. Brecher and T. Hatta (1983), "The generalized theory of transfers and welfare: bilateral transfers in a multilateral world,” The American Economic Review, Vol. 73, pp. 606-18.

Bowen, H.P., A. Hollander, and J-M. Viaene (1998), Applied International Trade Analysis, MacMillan, London.

Brakman, S., and C. Van Marrewijk (1998), The economics of international transfers, Cambridge University Press.

Chichilnisky, G. (1980), "Basic goods, the effects of commodity transfers and the international economic order," Journal of Development Economics 7: 505-519.

Chipman, J.S. (1974), "The transfer problem once again," in: Trade, stability and microeconomics, G. Horwicz and P.A. Samuelson, eds., pp. 19-78, Academic Press, New York and London. 
Dixit, A.K. and V. Norman (1980), The theory of international trade, Cambridge University Press, Cambridge, U.K.

Gale, D. (1974), "Exchange equilibrium and coalitions: an example," Journal of Mathematical Economics 1: 63-66.

Johnson, H. (1976), Notes on the classical transfer problem, The Manchester School, pp.211-219.

Jones, R.W. (1967), "International capital movements and the theory of tariffs and trade," Journal of International Economics 5: 263-274.

Jones, R.W. (1975), "Presumption and the transfer problem," Journal of International Economics, 5: 263-274.

Jones, R.W. (1985), "Income effects and paradoxes in the theory of international trade,” The Economic Journal, Vol 95, pp. 330-344.

Kershaw, I. (1999), Hitler, 1889-1936: Hubris, Penguin Books, London.

Kemp, M.C. (1964), The pure theory of international trade, Prentice-Hall, Englewood Cliffs, NJ.

Kemp, M.C. (1995), The gains from Trade and the gains from aid, Routledge, London.

Kemp, M.C., and S. Kojima (1985), "Tied aid and the paradoxes of donor-enrichment and recipient-impoverishment," International Economic Review 26: 721-729.

Kemp, M.C. and K.Shimomura (2003), A theory of Involuntary Unrequited International Tranfers, Journal of Political Economy, Vol. 111, pp686-692.

Keynes, J.M (1919). The Economic Consequences of the Peace, MacMillan, London.

Keynes, J.M. (1929a), "The German transfer problem," The Economic Journal 39: 17.

Keynes, J.M. (1929b), "The reparations problem: a discussion. II. A rejoinder," The Economic Journal 39: 179-82.

Keynes, J.M. (1929c), "Mr. Keynes' views on the transfer problem. III. A reply," The Economic Journal 39: 404-8.

Krugman, P.R., and M. Obstfeld (2006), International economics: theory and policy, $7^{\text {th }}$ edition, Pearson International Edition, Boston, etc.

Leontief, W. (1936), "A note on the pure theory of transfers," in: Explorations in economics: notes and essays contributed in honor of F.W. Taussig, McGraw Hill, New York. 
McDougall, I. (1965), "Non-traded goods and the transfers problem," Review of Economic Studies, 32: 67-84.

Mundell, R.A. (1960), "The pure theory of international trade," American Economic Review, 50: 67-110.

Ohlin, B. (1929a), "The reparations problem: a discussion; transfer difficulties, real and imagined," The Economic Journal 39: 172-83.

Ohlin, B. (1929b), "Mr. Keynes' views on the transfer problem. II. A rejoinder from professor Ohlin," The Economic Journal 39: 400-4.

Ohyama, M. (1974), "Tariffs and the transfer problem," KEIO Economic Studies 11: 29-45.

Samuelson, P.A. (1947), Foundations of economic analysis, Harvard University Press, Cambridge, MA.

Samuelson, P.A. (1971a), "Ohlin was right," Swedish Journal of Economics 73: 36584.

Samuelson, P.A. (1971b), "On the trail of conventional beliefs about the transfer problem," in: Trade, balance of payments and growth, J. Bhagwati et al., eds., pp. 327-354, North-Holland, Amsterdam.

Schweinberger, A.G. (1990), "On the welfare effects of tied aid," International Economic Review 31: 457-462.

Skidelsky, R. (1992), John Maynard Keynes: The Economist as Saviour, MacMillan, London.

Yano, M. and J.B. Nugent (1999), Aid, Nontraded Goods, and the Transfer Paradox in Small Countries, American Economic Review, Vol.89, pp. 431-449. 


\section{Appendix: Transfers, non-traded goods, and unemployment}

This appendix briefly derives the main results for the four models. The equation numbers refer to the equivalent numbers in the paper.

\section{Standard model}

(1) $\quad E^{A}\left(p, u^{A}\right)=R^{A}(p)-T$

(4) $\quad E^{B}\left(p, u^{B}\right)=R^{B}(p)+T$

(6) $\quad m^{A}\left(p, u^{A}\right)+m^{B}\left(p, u^{B}\right)=0$

Normalize $E_{u}^{J}=1$ and define $\Omega \equiv \sum_{J} m_{p}^{J}<0$ and $-1 / \Delta \equiv \Omega-m^{A} m_{u}^{A}-m^{B} m_{u}^{B}<0$.

Differentiate with respect to $p, u^{A}, u^{B}$ and $T$ and solve:

$$
\begin{aligned}
& {\left[\begin{array}{ccc}
m^{A} & 1 & 0 \\
m^{B} & 0 & 1 \\
\Omega & m_{u}^{A} & m_{u}^{B}
\end{array}\right]\left[\begin{array}{c}
d p \\
d u^{A} \\
d u^{B}
\end{array}\right]=\left[\begin{array}{c}
-1 \\
1 \\
0
\end{array}\right] d T} \\
& \frac{d p}{d T}=\left(m_{u}^{B}-m_{u}^{A}\right) \Delta>0 \Leftrightarrow m_{u}^{B}>m_{u}^{A} \\
& \frac{d u^{A}}{d T}=\Omega \Delta<0 ; \quad \frac{d u^{B}}{d T}=-\Omega \Delta>0 ; \quad \frac{d u^{A}}{d T}+\frac{d u^{B}}{d T}=0
\end{aligned}
$$

\section{Non-traded goods model}

(1) $\quad E^{A}\left(p, q^{A}, u^{A}\right)=R^{A}\left(p, q^{A}\right)-T$

(2) $\quad E_{q}^{A}\left(p, q^{A}, u^{A}\right)=R_{q}^{A}\left(p, q^{A}\right)$

(4) $\quad E^{B}\left(p, q^{B}, u^{B}\right)=R^{B}\left(p, q^{B}\right)+T$

(5) $\quad E_{q}^{B}\left(p, q^{B}, u^{B}\right)=R_{q}^{B}\left(p, q^{B}\right)$

(6) $\quad m^{A}\left(p, q^{A}, u^{A}\right)+m^{B}\left(p, q^{B}, u^{B}\right)=0$

Solve (2) and (5) for the price of non-traded goods and substitute in (1), (4), and (6):

(1) $\quad E^{A}\left(p, q^{A}\left(p, u^{A}\right), u^{A}\right)=R^{A}\left(p, q^{A}\left(p, u^{A}\right)\right)-T$

(4) $\quad E^{B}\left(p, q^{B}\left(p, u^{B}\right), u^{B}\right)=R^{B}\left(p, q^{B}\left(p, u^{B}\right)\right)+T$

(6) $\quad m^{A}\left(p, q^{A}\left(p, u^{A}\right), u^{A}\right)+m^{B}\left(p, q^{B}\left(p, u^{A}\right), u^{B}\right)=0$ 
Define $\quad q_{p}^{J} \equiv-\left(E_{q p}^{J}-R_{q p}^{J}\right) /\left(E_{q q}^{J}-R_{q q}^{J}\right) ; \quad q_{u}^{J} \equiv-E_{q u}^{J} /\left(E_{q q}^{J}-R_{q q}^{J}\right) ; \quad \bar{m}_{u}^{J} \equiv m_{u}^{J}+m_{q}^{J} q_{u}^{J} ;$

$\bar{\Omega}=\sum_{J}\left(m_{p}^{J}-\left(m_{q}^{J}\right)^{2} /\left(E_{q q}^{J}-R_{q q}^{J}\right)\right)<0$; and $-1 / \bar{\Delta} \equiv \bar{\Omega}-m^{A} \bar{m}_{u}^{A}-m^{B} \bar{m}_{u}^{B}<0$.

Differentiate with respect to $p, u^{A}, u^{B}$ and $T$ and solve:

$$
\begin{aligned}
& {\left[\begin{array}{ccc}
m^{A} & 1 & 0 \\
m^{B} & 0 & 1 \\
\bar{\Omega} & \bar{m}_{u}^{A} & \bar{m}_{u}^{B}
\end{array}\right]\left[\begin{array}{c}
d p \\
d u^{A} \\
d u^{B}
\end{array}\right]=\left[\begin{array}{c}
-1 \\
1 \\
0
\end{array}\right] d T} \\
& \frac{d p}{d T}=\left(\bar{m}_{u}^{B}-\bar{m}_{u}^{A}\right) \bar{\Delta}>0 \Leftrightarrow \bar{m}_{u}^{B}>\bar{m}_{u}^{A} \\
& \frac{d u^{A}}{d T}=\bar{\Omega} \bar{\Delta}<0 ; \quad \frac{d u^{B}}{d T}=-\bar{\Omega} \bar{\Delta}>0 ; \quad \frac{d u^{A}}{d T}+\frac{d u^{B}}{d T}=0
\end{aligned}
$$

\section{Unemployment model}

(1) $\quad E^{A}\left(p, u^{A}\right)=R^{A}\left(p, v^{A}\right)-T$

(3) $\quad R_{v}^{A}\left(p, v^{A}\right)=w^{A}$

(4) $\quad E^{B}\left(p, u^{B}\right)=R^{B}(p)+T$

(6) $\quad m^{A}\left(p, u^{A}, v^{A}\right)+m^{B}\left(p, u^{B}\right)=0$

Let $\varepsilon^{A} \equiv\left(\partial w^{A} / \partial p\right)\left(p / w^{A}\right)=R_{p v}^{A}\left(p / R_{v}^{A}\right) ; \quad \eta^{A} \equiv-\left(\partial w^{A} / \partial v\right)\left(v / w^{A}\right)=-R_{v v}^{A}\left(v / R_{v}^{A}\right)$;

$$
\text { and } \left.-1 / \tilde{\Delta} \equiv-1 / \Delta+\left(\varepsilon^{A} w^{A} v / \eta^{A} p^{2}\right)\left(p m_{u}^{A}-\varepsilon^{A}\right)<0 \text {. (note: } m_{v}^{A}=-R_{p v}^{A}\right)
$$

Differentiate with respect to $p, u^{A}, u^{B}, v^{A}$ and $T$ and solve:

$$
\begin{aligned}
& {\left[\begin{array}{cccc}
m^{A} & 1 & 0 & -w_{A} \\
m^{B} & 0 & 1 & 0 \\
\Omega & m_{u}^{A} & m_{u}^{B} & m_{v}^{A} \\
R_{v p}^{A} & 0 & 0 & R_{v v}^{A}
\end{array}\right]\left[\begin{array}{c}
d p \\
d u^{A} \\
d u^{B} \\
d v^{A}
\end{array}\right]=\left[\begin{array}{c}
-1 \\
1 \\
0 \\
0
\end{array}\right] d T} \\
& \frac{d p}{d T}=\left(m_{u}^{B}-m_{u}^{A}\right) \tilde{\Delta}>0 \Leftrightarrow m_{u}^{B}>m_{u}^{A} \\
& \frac{d u^{A}}{d T}=-1-m^{A} \frac{d p}{d T}+w^{A} \frac{d v^{A}}{d T} ; \frac{d u^{B}}{d T}=1-m^{B} \frac{d p}{d T} \\
& \frac{d u^{A}}{d T}+\frac{d u^{B}}{d T}=w^{A} \frac{d v^{A}}{d T}=\frac{\varepsilon^{A} w^{A} v^{A}}{\eta^{A} p} \frac{d p}{d T}
\end{aligned}
$$




\section{Complete model}

(1) $\quad E^{A}\left(p, q^{A}, u^{A}\right)=R^{A}\left(p, q^{A}, v^{A}\right)-T$

(2) $\quad E_{q}^{A}\left(p, q^{A}, u^{A}\right)=R_{q}^{A}\left(p, q^{A}, v^{A}\right)$

(3) $\quad R_{v}^{A}\left(p, q^{A}, v^{A}\right)=w^{A}$

(4) $\quad E^{B}\left(p, q^{B}, u^{B}\right)=R^{B}\left(p, q^{B}\right)+T$

(5) $\quad E_{q}^{B}\left(p, q^{B}, u^{B}\right)=R_{q}^{B}\left(p, q^{B}\right)$

(6) $\quad m^{A}\left(p, q^{A}, u^{A}, v^{A}\right)+m^{B}\left(p, q^{B}, u^{B}\right)=0$

Solve (2) and (5) for the price of non-traded goods; substitute in (1), (3), (4), and (6):

(1) $\quad E^{A}\left(p, q^{A}\left(p, u^{A}, v^{A}\right), u^{A}\right)=R^{A}\left(p, q^{A}\left(p, u^{A}, v^{A}\right)\right)-T$

(3) $\quad R_{v}^{A}\left(p, q^{A}\left(p, u^{A}, v^{A}\right), v^{A}\right)=w^{A}$

(4) $\quad E^{B}\left(p, q^{B}\left(p, u^{B}\right), u^{B}\right)=R^{B}\left(p, q^{B}\left(p, u^{B}\right)\right)+T$

(6) $\quad m^{A}\left(p, q^{A}\left(p, u^{A}\right), u^{A}\right)+m^{B}\left(p, q^{B}\left(p, u^{A}\right), u^{B}\right)=0$

$q_{v}^{A} \equiv R_{q v}^{A} /\left(E_{q q}^{A}-R_{q q}^{A}\right) ; \bar{m}_{v}^{A}=\left(m_{v}^{A}+m_{q}^{A} q_{v}^{A}\right) ; \bar{R}_{p v}^{A} \equiv\left(R_{p v}^{A}+R_{v q}^{A} q_{v}^{A}\right) ; \bar{R}_{v v}^{A} \equiv\left(R_{v v}^{A}+R_{v q}^{A} q_{v}^{A}\right) ;$

$\bar{R}_{v u}^{A} \equiv R_{v q}^{A} q_{u}^{A} ;-1 / \hat{\Delta} \equiv\left(1+w^{A} \bar{R}_{v u}^{A} / \bar{R}_{v v}^{A}\right)(-1 / \bar{\Delta})+\left(m^{A} \bar{R}_{v u}^{A}-\bar{R}_{v p}^{A}\right)\left(w^{A} \bar{m}_{u}^{A}+\bar{m}_{v}^{A}\right) / \bar{R}_{v v}^{A}<0$.

Differentiate with respect to $p, u^{A}, u^{B}, v^{A}$ and $T$ and solve:

$$
\begin{aligned}
& {\left[\begin{array}{cccc}
m^{A} & 1 & 0 & -w_{A} \\
m^{B} & 0 & 1 & 0 \\
\bar{\Omega} & \bar{m}_{u}^{A} & \bar{m}_{u}^{B} & \bar{m}_{v}^{A} \\
\bar{R}_{v p}^{A} & \bar{R}_{v u}^{A} & 0 & \bar{R}_{v v}^{A}
\end{array}\right]\left[\begin{array}{c}
d p \\
d u^{A} \\
d u^{B} \\
d v^{A}
\end{array}\right]=\left[\begin{array}{c}
-1 \\
1 \\
0 \\
0
\end{array}\right] d T} \\
& d p / d T=\left[\left(\bar{m}_{u}^{B}-\bar{m}_{u}^{A}\right)+\left(\bar{R}_{v u}^{A} / \bar{R}_{v v}^{A}\right)\left(w^{A} \bar{m}_{u}^{A}+\bar{m}_{v}^{A}\right)\right] \hat{\Delta} \\
& \frac{d u^{A}}{d T}=-1-m^{A} \frac{d p}{d T}+w^{A} \frac{d v^{A}}{d T} ; \quad \frac{d u^{B}}{d T}=1-m^{B} \frac{d p}{d T} \\
& \frac{d u^{A}}{d T}+\frac{d u^{B}}{d T}=w^{A} \frac{d v^{A}}{d T} \\
& \frac{d v^{A}}{d T}=\left[\left(\bar{m}_{u}^{B}-\bar{m}_{u}^{A}\right)-\left(\bar{R}_{v u}^{A} / \bar{\Delta}\right)\right]\left(\hat{\Delta} / \bar{R}_{v v}^{A}\right)
\end{aligned}
$$




\section{CESifo Working Paper Series}

(for full list see www.cesifo-group.de)

1525 Alexander Kemnitz, Can Immigrant Employment Alleviate the Demographic Burden? The Role of Union Centralization, August 2005

1526 Baoline Chen and Peter A. Zadrozny, Estimated U.S. Manufacturing Production Capital and Technology Based on an Estimated Dynamic Economic Model, August 2005

1527 Marcel Gérard, Multijurisdictional Firms and Governments' Strategies under Alternative Tax Designs, August 2005

1528 Joerg Breitscheidel and Hans Gersbach, Self-Financing Environmental Mechanisms, August 2005

1529 Giorgio Fazio, Ronald MacDonald and Jacques Mélitz, Trade Costs, Trade Balances and Current Accounts: An Application of Gravity to Multilateral Trade, August 2005

1530 Thomas Christiaans, Thomas Eichner and Ruediger Pethig, A Micro-Level 'Consumer Approach’ to Species Population Dynamics, August 2005

1531 Samuel Hanson, M. Hashem Pesaran and Til Schuermann, Firm Heterogeneity and Credit Risk Diversification, August 2005

1532 Mark Mink and Jakob de Haan, Has the Stability and Growth Pact Impeded Political Budget Cycles in the European Union?, September 2005

1533 Roberta Colavecchio, Declan Curran and Michael Funke, Drifting Together or Falling Apart? The Empirics of Regional Economic Growth in Post-Unification Germany, September 2005

1534 Kai A. Konrad and Stergios Skaperdas, Succession Rules and Leadership Rents, September 2005

1535 Robert Dur and Amihai Glazer, The Desire for Impact, September 2005

1536 Wolfgang Buchholz and Wolfgang Peters, Justifying the Lindahl Solution as an Outcome of Fair Cooperation, September 2005

1537 Pieter A. Gautier, Coen N. Teulings and Aico van Vuuren, On-the-Job Search and Sorting, September 2005

1538 Leif Danziger, Output Effects of Inflation with Fixed Price- and Quantity-Adjustment Costs, September 2005

1539 Gerhard Glomm, Juergen Jung, Changmin Lee and Chung Tran, Public Pensions and Capital Accumulation: The Case of Brazil, September 2005 
1540 Yvonne Adema, Lex Meijdam and Harrie A. A. Verbon, The International Spillover Effects of Pension Reform, September 2005

1541 Richard Disney, Household Saving Rates and the Design of Social Security Programmes: Evidence from a Country Panel, September 2005

1542 David Dorn and Alfonso Sousa-Poza, Early Retirement: Free Choice or Forced Decision?, September 2005

1543 Clara Graziano and Annalisa Luporini, Ownership Concentration, Monitoring and Optimal Board Structure, September 2005

1544 Panu Poutvaara, Social Security Incentives, Human Capital Investment and Mobility of Labor, September 2005

1545 Kjell Erik Lommerud, Frode Meland and Odd Rune Straume, Can Deunionization Lead to International Outsourcing?, September 2005

1546 Robert Inklaar, Richard Jong-A-Pin and Jakob de Haan, Trade and Business Cycle Synchronization in OECD Countries: A Re-examination, September 2005

1547 Randall K. Filer and Marjorie Honig, Endogenous Pensions and Retirement Behavior, September 2005

1548 M. Hashem Pesaran, Til Schuermann and Bjoern-Jakob Treutler, Global Business Cycles and Credit Risk, September 2005

1549 Ruediger Pethig, Nonlinear Production, Abatement, Pollution and Materials Balance Reconsidered, September 2005

1550 Antonis Adam and Thomas Moutos, Turkish Delight for Some, Cold Turkey for Others?: The Effects of the EU-Turkey Customs Union, September 2005

1551 Peter Birch Sørensen, Dual Income Taxation: Why and how?, September 2005

1552 Kurt R. Brekke, Robert Nuscheler and Odd Rune Straume, Gatekeeping in Health Care, September 2005

1553 Maarten Bosker, Steven Brakman, Harry Garretsen and Marc Schramm, Looking for Multiple Equilibria when Geography Matters: German City Growth and the WWII Shock, September 2005

1554 Paul W. J. de Bijl, Structural Separation and Access in Telecommunications Markets, September 2005

1555 Ueli Grob and Stefan C. Wolter, Demographic Change and Public Education Spending: A Conflict between Young and Old?, October 2005

1556 Alberto Alesina and Guido Tabellini, Why is Fiscal Policy often Procyclical?, October 2005 
1557 Piotr Wdowinski, Financial Markets and Economic Growth in Poland: Simulations with an Econometric Model, October 2005

1558 Peter Egger, Mario Larch, Michael Pfaffermayr and Janette Walde, Small Sample Properties of Maximum Likelihood Versus Generalized Method of Moments Based Tests for Spatially Autocorrelated Errors, October 2005

1559 Marie-Laure Breuillé and Robert J. Gary-Bobo, Sharing Budgetary Austerity under Free Mobility and Asymmetric Information: An Optimal Regulation Approach to Fiscal Federalism, October 2005

1560 Robert Dur and Amihai Glazer, Subsidizing Enjoyable Education, October 2005

1561 Carlo Altavilla and Paul De Grauwe, Non-Linearities in the Relation between the Exchange Rate and its Fundamentals, October 2005

1562 Josef Falkinger and Volker Grossmann, Distribution of Natural Resources, Entrepreneurship, and Economic Development: Growth Dynamics with Two Elites, October 2005

$1563 \mathrm{Yu}-\mathrm{Fu}$ Chen and Michael Funke, Product Market Competition, Investment and Employment-Abundant versus Job-Poor Growth: A Real Options Perspective, October 2005

1564 Kai A. Konrad and Dan Kovenock, Equilibrium and Efficiency in the Tug-of-War, October 2005

1565 Joerg Breitung and M. Hashem Pesaran, Unit Roots and Cointegration in Panels, October 2005

1566 Steven Brakman, Harry Garretsen and Marc Schramm, Putting New Economic Geography to the Test: Free-ness of Trade and Agglomeration in the EU Regions, October 2005

1567 Robert Haveman, Karen Holden, Barbara Wolfe and Andrei Romanov, Assessing the Maintenance of Savings Sufficiency Over the First Decade of Retirement, October 2005

1568 Hans Fehr and Christian Habermann, Risk Sharing and Efficiency Implications of Progressive Pension Arrangements, October 2005

1569 Jovan Žamac, Pension Design when Fertility Fluctuates: The Role of Capital Mobility and Education Financing, October 2005

1570 Piotr Wdowinski and Aneta Zglinska-Pietrzak, The Warsaw Stock Exchange Index WIG: Modelling and Forecasting, October 2005

1571 J. Ignacio Conde-Ruiz, Vincenzo Galasso and Paola Profeta, Early Retirement and Social Security: A Long Term Perspective, October 2005 
1572 Johannes Binswanger, Risk Management of Pension Systems from the Perspective of Loss Aversion, October 2005

1573 Geir B. Asheim, Wolfgang Buchholz, John M. Hartwick, Tapan Mitra and Cees Withagen, Constant Savings Rates and Quasi-Arithmetic Population Growth under Exhaustible Resource Constraints, October 2005

1574 Christian Hagist, Norbert Klusen, Andreas Plate and Bernd Raffelhueschen, Social Health Insurance - the Major Driver of Unsustainable Fiscal Policy?, October 2005

1575 Roland Hodler and Kurt Schmidheiny, How Fiscal Decentralization Flattens Progressive Taxes, October 2005

1576 George W. Evans, Seppo Honkapohja and Noah Williams, Generalized Stochastic Gradient Learning, October 2005

1577 Torben M. Andersen, Social Security and Longevity, October 2005

1578 Kai A. Konrad and Stergios Skaperdas, The Market for Protection and the Origin of the State, October 2005

1579 Jan K. Brueckner and Stuart S. Rosenthal, Gentrification and Neighborhood Housing Cycles: Will America's Future Downtowns be Rich?, October 2005

1580 Elke J. Jahn and Wolfgang Ochel, Contracting Out Temporary Help Services in Germany, November 2005

1581 Astri Muren and Sten Nyberg, Young Liberals and Old Conservatives - Inequality, Mobility and Redistribution, November 2005

1582 Volker Nitsch, State Visits and International Trade, November 2005

1583 Alessandra Casella, Thomas Palfrey and Raymond Riezman, Minorities and Storable Votes, November 2005

1584 Sascha O. Becker, Introducing Time-to-Educate in a Job Search Model, November 2005

1585 Christos Kotsogiannis and Robert Schwager, On the Incentives to Experiment in Federations, November 2005

1586 Søren Bo Nielsen, Pascalis Raimondos-Møller and Guttorm Schjelderup, Centralized vs. De-centralized Multinationals and Taxes, November 2005

1587 Jan-Egbert Sturm and Barry Williams, What Determines Differences in Foreign Bank Efficiency? Australian Evidence, November 2005

1588 Steven Brakman and Charles van Marrewijk, Transfers, Non-Traded Goods, and Unemployment: An Analysis of the Keynes - Ohlin Debate, November 2005 